\title{
Assessment the Calf's Welfare Due to The Gender, Number of Offspring and Calving Status in Holstein Calves
}

\author{
Azhar F. Abdel Fattah ${ }^{*}$, Hesham H. Mohammed ${ }^{1}$, Mohamed I. Youssef ${ }^{1}$, Al-Sadik Y \\ Saleem $^{1}$, Ibrahim Youniss ${ }^{2}$
}

${ }^{1}$ Department of Veterinary Public Health, Faculty of Veterinary Medicine, Zagazig University, Egypt, ${ }^{2}$ Inspection Department of Kom-Ombo Veterinary Services, Aswan Governorate, Egypt.

\section{Abstract}

The aim of the present paper was to study the influence of gender, number of offspring, calving status on both health and welfare. Out of 3000 heads, data for 429 Holstein female calves and 551 male calves which have been born during one year were used with computer records. The result suggested that abnormal behaviour during $1^{\text {st }} 12$ hours of calf's life have been significantly affected by twinning and dystocia. The presence and duration of behaviour related to respiratory, digestive or mixed disorders were significantly higher in females, the calf's growth rate was higher in male than female with significance difference, while its birth weight was significantly higher in dystocia than calves from normal parturition. There was a non-significant effect of calf gender, number of offspring and parturition state on calves weaning age. It could be concluded that Calf gender, number of offspring and parturition state have a different effects on behaviour and growth performance of calves from birth till weaning. Abnormal behaviours during the first 12 hours of calf's life as delayed sternal recumbancy, standing, abnormal suckling have been significantly affected by twinning and dystocia and not significantly affected by calf sex. Presence and duration of behaviour related to respiratory, digestive or mixed disorders were significantly higher in females than males, where these disorders were significantly higher in case of dystocia and twinning births. Culling of cows with incidence of twinning is recommended to control the decreased fertility, decreased total number of calves over the lifespan of the cow, and decreased milk production.

Keywords: Calf, Calving, Gender, Twining, Weaning.

DOI: $10.21608 / \mathrm{svu} .2019 .6656 .1002$

Received: December 15, $2018 \quad$ Accepted: February 24, $2019 \quad$ Published: April 20, 2019

*Corresponding Author: Azhar F. Abdel Fattah E-mail: azharfakhry65@yahoo.com

Citation: Abdel Fattah et al., Assessment the calf's welfare due to the gender, number of off spring and calving status in Holstein calves. SVU-IJVS 2019, 2 (1): 119-130.

Copyright: (C) Abdel Fattah et al. This is an open access article distributed under the terms of the creative common attribution license, which permits unrestricted use, distribution and reproduction in any medium provided the original author and source are created.

Competing interest: The authors have declared that no competing interest exists. 


\section{Introduction}

Understanding the behaviour of calves and the factors that affect them helps to improve their management during the preweaning period. Pre-weaning is the most important period of calves' life and it can reduce the negative consequences on their health and productive performance. Calf gender had no effect on the time from birth to successful standing as the results showed that one heifer calf and 4 bull calves stood up in the first hour of life and in the second $\mathrm{d}$ hour, the first successful standing attempt occurred in 6 heifer calves and 4 bull calves (Neja 2013).

Calving twin in Holstein Friesian dairy cattle is 3-5\%. Reproduction problems present around the time of parturition resulted in decrease economic gain. Single calves and also analyzing the milk production of dairy cows both before and after calving and compared by twin. Cows with twins became within early pregnancy, because with better fertility and health, with short pregnancy period and calving interval. However, after parturition, cows have twins appear with poor reproductive performance. Twincalving cows have better condition before calving, with losses during twin calving, metabolic disorders of the cow, and low vitality of the twin calves, decrease fertility and increase culling rate in cows after twinning and discourage breeding twins in dairy cattle (Gáspárdy et al., 2018)

Twin calving has several bad consequences such as abortion, difficult birth, high mortality of the offspring at birth, and increased incidence of placenta retention seen frequently in twin-calving cows (Szelényi et al., 2009).

Maternal behavior is a clear behavior that expressed by dam during pregnancy, previous and during parturition and that is directed towards the calves during suckling until they weaned. Most systems of dairy cattle success depend on the maternal behavior, in dairy stock extensive systems of such as double-purpose cattle that are very common in some regions of the world, and even in some types of organic dairies make use of the benefits of natural maternal behavior too(Garcia 2018).

The physiological influence of dystocia on calves leads to fatalities or decrease their survival rate. Dystocia exposed off spring to detrimental effects on their accommodation to external life. These need more interest as compared to those delivered calves without help .Calves with severe dystocia, generally present problems that can be immediately fatal; calves that prolonged hypoxia and survive are often weak and slow to stand and suckle. These deficiencies compromise the ingestion of colostrum. Moreover, dystocia is source of several problems affecting on the calf after birth. Calves exposed to severe dystocia may have persistent pathophysiological effects that raise their mortality rate as abnormal respiration, coughing, behavioral signs related to digestive disorders as diarrhea (Lombard et al., 2007). So, all breeders focus the light importance on calves yield in farms in all over the world for the future of the herd to obtaining cows with high economics gain and low losses. For that reason, the objectives of this study were as follows:

1- The effect of gender difference on calf's behaviour and performance from birth till weaning.

2- The effect of number of calves on behaviour and performance from birth till weaning.

3- The effect of parturition status on calf's behaviour and performance from birth till weaning.

\section{Materials and Methods}

I. Animals used and management: 
This study was carried out at a private dairy farm at El-Amal at Cairo-Ismailia road with total number of 3000 heads.

Four hundreds twenty nine female and 551 male Holstein calves from apparently healthy dams during one year, calves were separated from the dams on the first day and reared in individual hutches after birth till weaning. Calf hutches are strong plastic structures with an opening on one side that leads to the outside into the perimeter fence and littered with sand for thermal comfort.

The cows were kept in holding yards with an average capacity of 25 to 30 heads for each one with a sandy surface, metal bars fences and pipes and the roof was half opened and half sheltered. Before parturition by few days the pregnant cows were isolated in single calving pens with straw bed few days. Navel disinfection was performed for both the internal and external surfaces of the umbilicus by dipping the naval into fresh iodine. All calves were subjected to dehorning at one month-old.

Calves suckling colostrum collected from their mother collected after birth by 1 hour and received (1.5-2 liters) at the beginning then gradually increased to 7-8 liters within the first 24 hours (Zábranský et al., 2015). Milk fed at amount of $5 \mathrm{~L} / \mathrm{d}$ divided into 2 portions offered in the morning and evening for 56 days and increase to $2.0 \%$ of the body weight until weaning( Ribeiro et al., 2009). The calves had a free access to drinking water for the entire experimental period. A Starter ration has been offered right away from first days of age till weaning (Jami et al., 2013). Calves received $113 \mathrm{~g}$ of starter in the morning and evening (Orellana and Ruth 2016). Calves weaned after they consumed $1 \mathrm{~kg}$ of starter daily (Stamey et al., 2012) with a minimum body weight at weaning not less than 55-56 kg. Once weaned, calves were moved in small groups (10-20 calves) in to small barns with different nutritional materials of dry feed and high quality hay. Numerical identification of calves was made by using ear tags.

\section{Experimental design:}

At the date of calving, sex, breed, presence of dystocia and colostrum delivery strategy to the calves were recorded. Data for all calves under study were recorded from direct observation and computer records in the dairy farm during the period from for period of one year. Calves groups have been classified according to calf gender: (male and female), number of offspring (single and twins) and calving condition (normal and dystocia)

\section{Behavioural observations:}

III. I. Behavioural observations at the first day of caving:

Four hundreds twenty nine female and 551 male Holstein calves had been observed by direct observation using a stop watch, video camera and observation sheet immediately after birth and throughout the first 12 hours postpartum. The observed behaviour pattern according to Lorenz et al., (2011) included:

a- Sternal recumbancy: calves attained sternal recumbancy within 5 minutes after calving were recorded as normal calves and other calves with delayed time taken to attain sternal recumbancy over 5 minutes recorded as abnormal.

b- Standing : calves stood spontaneously within 60 -90 minutes after calving were recorded as normal calves and other calves with delayed time of standing onset over 60-90 minutes recorded as abnormal 
c- Suckling: calves which were unable to suckle normally recorded as abnormal.

III. II. Behavioural observations during pre-weaning period in calves:

Direct behavioural observation of calves was done using scanning technique according to Fraser and Broom (1990) through observing and recording the behaviour of each calf in the group twice a day for one hour using a stop watch, video camera and documented for each calf in an individual sheet. The observed behaviour pattern includes:

III. II. 1- Behavioural signs related to respiratory disorders.

a) Abnormal respiration: Increased resting respiratory rate, sound or effort and fever $\left(>39.5{ }^{\circ} \mathrm{C}\right)$ with one or more additional signs such as coughing, nasal discharge, depression, decreased appetite (Windeyer et al., 2014).

b) Coughing: The presences of induced spontaneous or repeated coughs had been used to identify calves with early respiratory disease (Pousen and McGuirk 2009).

Calves which had at least 2 clinical signs of respiratory disease were considered sick and were subjected to appropriate treatment (Panousis 2009)

III. II. 2- Behavioural signs related to digestive disorders.

a) Diarrhea (scours): characterized by increased frequency, fluidity or volume of faecal excretion in calves caused by excessive osmotic pressure in the intestine, intestinal damage or excessive contractions of the intestine (Lorenz 2006). Observations of faeces and health condition had been evaluated twice a day at the time of feeding (Zábranský et al., 2015).
III. II. 3- Behavioural signs related to mixed disorders.

Calf showed mixed signs of the both disorders; digestive and respiratory disorders.

IV-Calves performance:

Calf Birth Weight (CBW) was recorded for all calves within two hours after birth.

Live Body Weight (LBW) was recorded every month. At the time of weaning, the pre-weaning growth rate was calculated by the following equation:

$$
\text { Growth rate }=\frac{(\mathrm{W} 2-\mathrm{W} 1)}{(\mathrm{T} 2-\mathrm{T} 1)}
$$

Where W2 is the live weaning weight, $\mathrm{W} 1$ is the calf birth weight.

$\mathrm{T} 2-\mathrm{T} 1=$ weaning age which is the time interval from birth (T1) till weaning (T2)

\section{$V$ - Statistical analysis:}

All statistical procedures were performed using the SAS statistical system Package V9.2 (SAS, 2009). One-factorial analysis of variance (ANOVA) was performed. The analysis of data distribution suggested that all traits analyzed followed a normal distribution ( $P>0.05)$. Differences between means due to sex, number of offspring and parturition status were tested by Student's t-test. Pearson correlations were performed to compute the relationship of the abnormal behaviour and performance parameters.

\section{Results}

This study showed that behavioral disorders in female calves were higher than those in male calves, the durations of respiratory and digestive disorders were higher in females (0.28 and 0.70 day, respectively) as shown in table (1), there 
was an increase of birth weight and growth rate in male calves (37.62 and 0.54, respectively) in compare to female calves, While the age of weaning was higher in female calves (72.99 days) than that in male calves (67.78 days) as shown in table (2). Moreover, the data in table (3) revealed that abnormal behaviors were higher in twining calf than single calf; moreover, there was a significant increase in its duration (respiratory and digestive disorders). The results in table (4) showed that the birth weight and growth rate were higher in single calves $(36.53 \mathrm{~kg}$ and 0.59 $\mathrm{kg} /$ days, respectively) than twining calves (33.85 $\mathrm{kg}$ and $0.55 \mathrm{~kg} /$ days, respectively).
All abnormal behavior (1st 12 hrs, respiratory, digestive or mixed disorders) were higher in dystocia than normal parturition, durations of respiratory and digestive disorders were significantly higher in dystocia $(0.34 \pm 0.07 \mathrm{a}$ and $0.53 \pm 0.04 \mathrm{a}$, respectively) than normal status $(0.17 \pm 0.02 \mathrm{~b}$ and $0.41 \pm 0.07 \mathrm{~b}$, respectively), as shown in table (5). The data in table (6) showed that the entry birth weight was significantly higher in dystocia group $(36.51 \pm 0.56)$ than normal group (35.93 \pm 0.24$)$, also the pre-weaning growth rate was slightly higher in the normal group $(0.53 \pm 0.005)$ than dystocia group $(0.51 \pm 0.009)$

Table (1): The effect of sex difference on calves' health disorders related behaviour.

\begin{tabular}{|c|c|c|c|c|c|c|}
\hline \multirow{2}{*}{ Sex } & \multicolumn{6}{|c|}{ Behavioral disorders } \\
\cline { 2 - 7 } & $\begin{array}{c}\text { First 12hrs } \\
\text { abnormal } \\
\text { behaviour } \\
(\%)\end{array}$ & $\begin{array}{c}\text { Respiratory } \\
\text { disorders (\%) }\end{array}$ & $\begin{array}{c}\text { Digestive } \\
\text { disorders } \\
(\%)\end{array}$ & $\begin{array}{c}\text { Mixed } \\
\text { disorders } \\
(\%)\end{array}$ & $\begin{array}{c}\text { Respiratory } \\
\text { disorders } \\
\text { duration } \\
(\text { days })\end{array}$ & $\begin{array}{c}\text { Digestive } \\
\text { disorders } \\
\text { duration } \\
(\text { days) }\end{array}$ \\
\hline Male & $0.87 \%$ & $6.11 \%$ & $14.19 \%$ & $1.31 \%$ & $0.14 \pm 0.03^{\mathbf{b}}$ & $0.33 \pm 0.04^{\mathbf{b}}$ \\
\hline Female & $0.51 \%$ & $11.54 \%$ & $27.74 \%$ & $5.38 \%$ & $0.28 \pm 0.04^{\mathbf{a}}$ & $0.70 \pm 0.06^{\mathbf{a}}$ \\
\hline
\end{tabular}

Means in the same column with different superscripts are significantly different at $(\mathrm{P} \leq 0.05)$.

Table (2): The effect of sex difference on calves' performance.

\begin{tabular}{|c|c|c|c|}
\hline \multirow{2}{*}{ Sex } & \multicolumn{3}{|c|}{ Calves Performance } \\
\cline { 2 - 4 } & Birth weight (Kg) & Age of weaning (days) & Growth rate (Kg/day) \\
\hline Male & $37.62 \pm 0.31$ & $67.78 \pm 0.59$ & $0.54 \pm 0.01^{\mathbf{a}}$ \\
\hline Female & $34.22 \pm 0.29$ & $72.99 \pm 0.70$ & $0.51 \pm 0.01^{\mathbf{b}}$ \\
\hline
\end{tabular}

Means in the same column with different superscripts are significantly different at $(\mathrm{P} \leq 0.05)$. 
Table (3): The effect of number of offsprings on calves' health disorders related behaviour.

\begin{tabular}{|c|c|c|c|c|c|c|}
\hline \multirow{2}{*}{$\begin{array}{c}\text { Number } \\
\text { of } \\
\text { Offspring }\end{array}$} & \multicolumn{7}{|c|}{ Behavioral disorders } \\
\cline { 2 - 7 } & $\begin{array}{c}\text { First 12hrs } \\
\text { abnormal } \\
\text { behaviour } \\
(\%)\end{array}$ & $\begin{array}{c}\text { Respiratory } \\
\text { disorders } \\
(\%)\end{array}$ & $\begin{array}{c}\text { Digestive } \\
\text { disorders } \\
(\%)\end{array}$ & $\begin{array}{c}\text { Mixed } \\
\text { disorders } \\
(\%)\end{array}$ & $\begin{array}{c}\text { Respiratory } \\
\text { disorders } \\
\text { duration } \\
\text { (days) }\end{array}$ & $\begin{array}{c}\text { Digestive } \\
\text { disorders } \\
\text { duration } \\
\text { (days) }\end{array}$ \\
\hline Single & $0.50 \%$ & $7.80 \%$ & $20.63 \%$ & $2.89 \%$ & $0.18 \pm 0.02 \mathrm{~b}$ & $0.49 \pm 0.04^{\mathbf{b}}$ \\
\hline Twins & $3.77 \%$ & $20.75 \%$ & $32.08 \%$ & $7.55 \%$ & $0.51 \pm 0.15 \mathrm{a}$ & $0.72 \pm 0.15^{\mathbf{a}}$ \\
\hline
\end{tabular}

Means in the same column with different superscripts are significantly different at $(\mathrm{P} \leq 0.05)$.

Table (4): The effect of number of offsprings on calves' performance.

\begin{tabular}{|c|c|c|c|}
\hline \multirow{2}{*}{$\begin{array}{l}\text { Number } \\
\text { Offspring }\end{array}$} & \multicolumn{3}{|c|}{ Calves Performance } \\
\cline { 2 - 4 } Single & Birth weight (Kg) & Age of weaning (days) & Growth rate (Kg/days) \\
\hline Twins & $28.85 \pm 0.81$ & $69.96 \pm 0.48$ & $0.52 \pm 0.01$ \\
\hline
\end{tabular}

Table (5): The effect of parturition status on calves' health disorders related behaviour.

\begin{tabular}{|c|c|c|c|c|c|c|}
\hline \multirow{2}{*}{ Calving } & \multicolumn{7}{|c|}{ Behavioral disorders } \\
\cline { 2 - 7 } condition & $\begin{array}{c}\text { First 12hrs } \\
\text { abnormal } \\
\text { behaviour } \\
(\%)\end{array}$ & $\begin{array}{c}\text { Respiratory } \\
\text { disorders (\%) }\end{array}$ & $\begin{array}{c}\text { Digestive } \\
\text { disorders } \\
(\%)\end{array}$ & $\begin{array}{c}\text { Mixed } \\
\text { disorders } \\
(\%)\end{array}$ & $\begin{array}{c}\text { Respiratory } \\
\text { disorders } \\
\text { duration } \\
\text { (days) }\end{array}$ & $\begin{array}{c}\text { Digestive } \\
\text { disorders } \\
\text { duration } \\
\text { (days) }\end{array}$ \\
\hline Normal & $0.30 \%$ & $8.00 \%$ & $17.14 \%$ & $3.12 \%$ & $0.17 \pm 0.02 \mathrm{~b}$ & $0.41 \pm 0.07 \mathrm{~b}$ \\
\hline Dystocia & $2.29 \%$ & $12.57 \%$ & $22.29 \%$ & $3.43 \%$ & $0.34 \pm 0.07 \mathrm{a}$ & $0.53 \pm 0.04 \mathrm{a}$ \\
\hline
\end{tabular}

Means in the same column with different superscripts are significantly different at $(\mathrm{P} \leq 0.05)$.

Table (6): The relation between parturition status and calf performance.

\begin{tabular}{|c|c|c|c|}
\hline \multirow{2}{*}{$\begin{array}{c}\text { Calving } \\
\text { condition }\end{array}$} & \multicolumn{3}{|c|}{ Calves Performance } \\
\cline { 2 - 4 } & Birth weight $(\mathbf{K g})$ & Age of weaning (days) & Growth rate (Kg/day) \\
\hline Normal & $35.93 \pm 0.24^{\mathrm{b}}$ & $69.91 \pm 0.52$ & $0.53 \pm 0.01$ \\
\hline Dystocia & $36.51 \pm 0.56^{\mathrm{a}}$ & $71.19 \pm 0.98$ & $0.51 \pm 0.01$ \\
\hline
\end{tabular}

Means in the same column with different superscripts are significantly different at $(\mathrm{P} \leq 0.05)$. 


\section{Discussion}

Understanding the behaviour of calves and the factors that affect them helps to improve their management during the preweaning period which is the most important period of their life and can reduce the negative consequences on their health and productive performance.

Data in table (1) showed the effect of sex difference on calf's behavior, where these results are likely due to good performance in male calves in compare to female ones, as shown in table (2). Furthermore, the signs of soundness in male calves seem to be better than those in females, as previously mentioned by Asmare and Kiros (2016) who noted that more female calves were sick in compare to male calves. There were few recent researches that studied the effect of sex on calf's behavior; however Broucek et al., (2011) noted that calves behaviour differed according to bull lineage factor and in the case sex factor effect, only tendencies have been recorded with no significant differences. Nerveless, there were several studies that could not find significant difference in the most of maintenance behavior (Šochetal, 2011) and duration of standing behavior (Neja, 2013) between male and female calves. On the other hand, Mõtus et al., (2017) found that the most commonly reported reasons related to calf's mortality were respiratory disease and digestive disorders and according to the young stock models from 6 months of age, male sex was a risk factor for mortality.

The obtained results, as shown in table (2), revealed the increase of birth weight and growth rate in male than female calves, while the age of weaning was higher in female than male calves. This could be attributed to longer gestation period of male calves (Olson et al., 2009) or high androgen concentration in male fetuses. The obtained results agreed with Bakır et al., (2004) who reported that birth weight of male calves tend to be heavier than female calves. In another study, as mentioned by Olson et al., (2009) who found that female calves had lower birth weight and shorter gestation length than mall calves. Furthermore, (Aksakal and Bayram 2009) documented that male calves were found to have $1.7 \mathrm{~kg}$ higher birth weight than female ones.

Data in table (2) also revealed the effect of sex factor in calve performance, where the growth parameters were better in male calves. The birth weight in male calves was higher; nerveless the age of weaning had lower values in compare to female calves with no significance in these parameters. Furthermore, the growth rate was significantly higher in male than female calves. The obtained results were likely due to presence the androgenic hormones in male which had positive effect in body weight gain and growth rate. These results agreed with Koger and Knox (2009) who documented that male calves grow more rapidly than females and reach a higher mature weight, while females grow slower than males and reach maturity with a smaller size. Moreover, WielgoszGrith et al., (2015) mentioned that the final body weights of calves plus their daily gains were affected by calf gender during the rearing period with a higher daily gains and final body weight gained bulls. Nerveless, the previous studies did not found the significant effect of sex factor on growth performance in calves, as previously mentioned by Lambertzet al., (2015) who reported that significant differences between males and females on growth performance of the new born calves was not affected by the weaning age and sex interaction. The differences between the present results and previous 


studies may be due to changes in
environment, breed of calves or management inside the farm. Regarding to table (3) the obtained data revealed that the number of off springs significantly affects the health and behavior of pre-weaning calves. The percentages of all abnormal behavior were higher in twining calf than single; moreover, there was a significant increase in its duration (respiratory and digestive disorders). As general, the twinning group has been associated with a number of unfavorable effects as twin births showed significantly higher values for the presence and duration of behaviour related to respiratory, digestive or mixed disorders than that for the single group. These data agreed with those obtained by Fricke (2001), Gulliksen et al., (2009), Özden (2010), Mellado et al., (2014), and Gáspárdy et al., (2018); they concluded that twinning have been associated with a number of unfavorable effects, including lower calf vitality and increased rate of calf mortality mostly during the first month of life also increased incidence of dystocia due to weight and size of twin pairs. Sawa et al., (2015) reported that cows having twins were at greater risk for different perparturient metabolic and reproductive disorders than cows having single calves.

Growth parameters in table (4) showed no significant effect of the number of offspring on calf's performance, although the entry birth weight and growth rate were higher in single calves than twining calves, these obtained data agreed with that obtained by Aksakal and Bayram (2009), Olson et al., (2009), Fitzgerald et al., (2014), and Sawa et al., (2015) who reported that twin births mostly associated with lower birth weight of calves. While Bakır et al., (2004) found significant effect $(p<0.01)$ in the number of offspring (single vs. twin) on calf's birth weight. Moreover, Gaafar et al., (2010) mentioned that the average of both live body weight as well as daily weight gain at birth and weaning age have been significantly higher in single calves compared to twin calves.

The obtained data in table (5), revealed that the parturition status was significantly affected in the behaviour of pre-weaning calves. The percentages of all abnormal behavior ( $1^{\text {st }} 12$ hrs, respiratory, digestive or mixed disorders) were higher in dystocia than normal parturition. Hence, the status of parturition had significant effect in the durations of respiratory and digestive disorders, which were significantly higher in dystocia than normal status. The obtained results agreed with Neja (2013) who found that calving difficulty influence the vitality in $1^{\text {st }}$ period of the calves' life as there was a significant effect on the time from birth to successful calf standing. (Asmare and Kiros 2016, Rorvang et al., 2017) who concluded that dystocia leads to complications in dams (uterine infections) and newborn calves (weak enough to adapt to the external environment. Recently, Garcia (2018) noted that calves that have been experienced severe or prolonged dystocia, mostly presented asphyxia, trauma and other problems that could be immediately fatal weakness; slow to suckle and stand; problems in the ingest of colostrum and temperature regulation .

Table (6) showed the effect of the parturition status on calf's performance where the birth weight was significantly higher in dystocia than normal parturition. Moreover, table (6) showed slightly higher values of pre-weaning growth rate in the normal parturition than dystocia with a non-significant variation, there was a nonsignificant difference between single and twinning groups in the weaning age. This result may be due to a calf with higher weight at birth experienced more difficulty at calving, which agree with earlier studies 
reported that the calf weight is associated with dystocia (Johanson and Berger 2003, Berry et al., 2007, Lombard et al., 2007, Linden et al., 2009). Furthermore, the age of weaning in dystocia tend to be higher than that in normal parturition with no significance difference. Prolonged or sever dystocia commonly affected by prolonged hypoxia and significant acidosis (House 2002) which can be immediately reduce growth rate of calves, as shown in Table (6). The decrease of growth rate in dystocia (Table 6) revealed closely relation between poor calf performance and dystocia, as previously mentioned by Larson and Tyler (2005) who reported that poor calf performance is closely related to dystocia as well as increased susceptibility to the environmental pathogens which mostly cause calf diarrhea.

\section{Conclusion}

It could be concluded that calf gender, number of offspring and parturition status have different effects on behaviour and growth performance of calves from birth till weaning. Abnormal behaviours during the first 12 hours of calf's life as delayed sternal recumbancy, standing, and abnormal suckling have been significantly affected by twinning and dystocia and not significantly affected by the calf sex. Presence and duration of behaviour related to respiratory, digestive or mixed disorders were significantly higher in females than males, were significantly higher in case of dystocia and twinning births. Culling of cows with incidence of twinning should be taken into an account because this condition of twining was related to decreased fertility, decreasing the total number of calves over the lifespan of the cow, decrease in milk production. There was a non-significant effect of calf gender, number of offspring and parturition state on calves weaning age.

\section{Recommendation}

We strongly recommend more studies to achieve better understanding of the behaviour of calves and the factors that affect them to help improvement of their management during the pre-weaning period which is the most important period of their life, therefore, more ability to reduce the negative consequences on their health and productive performance. Decreasing the rate of twinning by using bulls with a low incidence for twinning for avoiding all negative consequences; however, many traits in bulls with value as milk solids or milk yields and female off spring with low growth rate, to choose bulls based on this.

\section{Conflict of interest statement}

The authors declare that they have no conflict of interest.

\section{Acknowledgement}

We are grateful to all members in the farm of El-Amal district, Cairo-Ismailia road, Cairo, Egypt for their help to conduct this study. We would like to thank anonymous referees for their helpful comments on the manuscript.

\section{References}

Aksakal V and Bayram B (2009). Estimates of genetic and phenotypic parameters for the birth weight of calves of Holstein Friesian cattle reared organically. Journal Animal Veterinary Advances, 8(3): 568-572.

Asmare A and Kiros W (2016). Dairy calf morbidity and mortality and associated risk factors in Sodo town and its suburbs, Wolaita zone, Ethiopia. Slovak Journal Animal Science, 49 (1): 44-56 


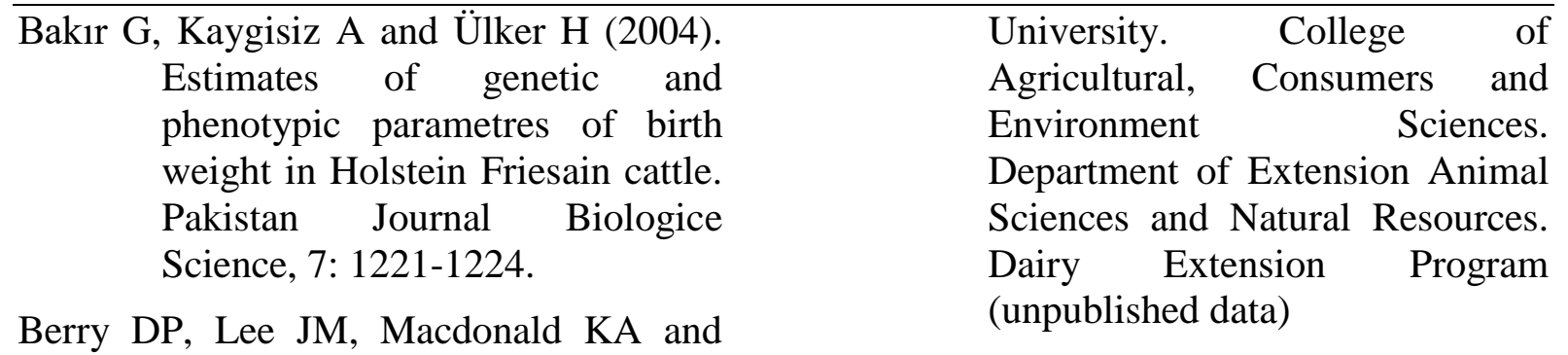
Roche JR (2007). Body condition score and body weight effects on dystocia and still births and consequent effects on post calving performance. Journal Dairy Science, 90: 4201-4211.

Brody S (1945). Growth and development. III. Growth rates, their evaluation and significance. Molecular, Agriculture Experimental Research Bulletin, 97.

Brouček J, Uhrinčat' $M$ and Hanus A (2011). Maintenance and competitive behaviour study in dairy calves. Slovak Journal Animal Science, 44 (1): 28-33.

Fitzgerald AM, Berry DP, Carth T, Cromie AR, and Ryan DP (2014). Risk factors associated with multiple ovulation and twin birth rate in Irish dairy and beef cattle. Journal Animal Science, 92: 966- 973.

Fraser AF and Broom DM (1990). Farm animal behaviour and welfare. 3rd Ed., Bailliere Tindall.

Fricke PM (2001). Twinning in dairy cattle. The Professional Animal Scientist, 17 (2): 61-67.

Gaafar H M A, Shitta AA, Shamiah SM and Ganah HA (2010). Productive performance of twin friesian calves in Egypt. Slovak Journal Animal Science, 43(4): 179-186.

Garcia BJ (2018). Aspects of behavior of dairy cattle around the calving period. New Mexico State

Gáspárdy $\mathrm{A}$, James $\mathrm{S}$, Melinda $\mathrm{A}$ and László G (2018). Twin Calving and Its Connection to Other Economically Important Traits in Dairy Cattle(C) 2018 The Author(s). Licensee Intech Open. This chapter is distributed under the terms of the Creative Commons Attribution License (http://creativecommons.org/licen ses/by/3.0), which permits unrestricted use, distribution, and reproduction in any medium, provided the original work is properly cited http://dx.doi.org/10.5772/intechop en.72905

Gulliksen SM, Lie KI, Loken T, Osteras O (2009) Calf mortality in Norwegian dairy herds. Journal of Dairy Science, 92: 2782-2795.

Hansen M, Lund MS, Pedersen J, Christensen LG (2004). Gestation length in Danish Holsteins has weak genetic associations with stillbirth, calving difficulty, and calf size. Livestock Production Science, 91: 23-33.

House JK (2002). Perinatal Adaptation, Asphyxia, and Resuscitation. In:"Large Animal Internal Medicine", (Ed.): Smith, B. P. 3rdEdition, Mosby St. Louis, MO. 266-267.

Jami E, Israel A, Kotser A and Mizrah I (2013). Exploring the bovine rumen bacterial community from 
birth to adulthood. International Society for Microbial Ecology. 7(6): 1069-1079.

Johanson JM and Berger PJ (2003). Birth weight as a predictor of calving ease and perinatal mortality in Holstein cattle. Journal of Dairy Science, 86: 3745-3755.

Koger M and Knox JH (2009). The effect of sex on weaning weight of range calves. Journal of Animal Science, 4: 15-19.

Lambertz C, Farke-Röver A, Gauly M (2015). Effects of sex and age on behavior and weight gain in beef calves after abrupt weaning. Animal Science Journal, 86: 345350.

Larson RL and Tyler JW (2005). Reducing calf losses in beef herds. Veterinary Clinic North American Food Animal Practice, 21 (2): 569-584.

Linden T C, Bicalho RC, Nydam DV (2009). Calf birth weight and its association with calf and cow survivability, disease incidence, reproductive performance, and milk production. Journal of Dairy Science, 92: 2580-2588.

Lombard JE, Garry FB, Tomlinson SM and Garber LP (2007). Impacts of dystocia on health and survival of dairy calves. Journal of Dairy Science, 90: 1751-1760.

Lorenz I (2006). Diarrhea of young calf: An update. Presented in World Buiatrics Congress 2006- Nice, France

Lorenz I, Mee J, Earley B, More S (2011). Calf health from birth to weaning in general aspects of disease prevention. Irish Veterinary

Journal 64: 1-8.

Mellado M, Lopez E, Veliz FG, De Santiago MA, Macias-Cruz, U, Avendaño-Reye L and Garcia JE (2014). Factors associated with neonatal dairy calf mortality in a hot-arid environment. Live Science, 159: 149-155.

Mõtus K, Viltrop A and Emanuelson U (2017). Reasons and risk factors for beef calf and young stock onfarm mortality in extensive cow calf herds. Animals, 26: 1-9.

Neja W (2013). Behaviour of calves in the first weeks of life. Journal of Central European Agriculture, 14(1): 33-41.

Nemzetközi Kongresszusának elöadásai. október 14-17. Debrecen. pp. 1219. ISBN: 978-963-87942-2-2

Orellana R and Ruth M (2016). Effects of Calf Starter Composition and Mixing Method on Growth and Rumen Health in Young Dairy Calves. LSU Master's Theses, Louisiana State University and Agricultural and Mechanical College, US.

Özden C (2010). Twinning in Cattle: Desirable or Undesirable? Journal of Biological and Environmental Science, 4(10): 1-8

Panousis N (2009). Dairy calf pneumonia: effective treatment depends on early and accurate diagnosis. Veterinarski Glasnik, 63(3-4): 177-187

Pousen KP and McGuirk MS (2009). Respiratory disease of the bovine neonate. Veterinary Clinic North American Food Animal Practice, 25(1): 121-137. 
Ribeiro MD, Pereira JC, Queiroz AC, Cecon PR, Detmann E, Azevêdo JA (2009). Performance of dairy calves fed milk, milk replacer or post-weaning concentrate with acidifiers. Brazilian Journal of Animal Science, 38 (5): 956-963.

Rorvang $\mathrm{M}$, Herskin $\mathrm{M}$ and Jensen $\mathrm{M}$ (2017). Dairy cows with prolonged calving seek additional isolation. Journal of Dairy Science, 100: 2967-2975

SAS (2009). SAS statistical system Package-Jmp 8 User's Guide.2nd Cary, NC, SAS Institute Inc. USA. ISBN 978-1-60764-301-2.

Sawa A, Bogucki $M$ and Glowska $M$ (2015). Effect of single and multiple pregancies on performance of premiparous and multiparous cows. Archive of Animal Breeding, 58: 43-48.

Šochetal M, Brouček J, Uhrinčat' $M$, Raabová M, Št'astná J,Tančin V, Novák P, Zajíček P (2011). Effects of Different Factors on Dairy Calves Behaviour. Scientific Papers. Animal Science and Biotechnology, 44 (2): 318.

Szelényi Z, Boldizsár S, Bajcsy ÁC, Szenci O (2009). Ikervemhesség előfordulása és a termelésre gyakorolt hatása hazai tejterelö állományokban. In: Szenci $\mathrm{O}$, Brydl E, Jurkovich V. editors. Termelni csak egészséges állatokkal lehet. A Magyar Buiatrikusok Társasága 19.

Wielgosz-Groth, Z, Sobczuk-Szul M, Nogalski Z, Purwin C, Pogorzelska-Przybyłek, Pand Winarski R (2015). The effect of gender and feeding system on the growth rate and blood parameters of Polish Holstein Friesian $\mathrm{x}$ Limousine calves. Pakistan Veterinary Journal, 35(1): 33-37.

Windeyer MC, Leslie KE, Godden SM, Hodgins DC, Lisseme KD, LeBlanc J (2014). Factors associated with morbidity, mortality, and growth of dairy heifer calves up to 3 months of age. Preventive Veterinary Medicine, 113(2): 231-240.

Zábranský L, Šoch M, Brouček J, Nová P, Tejml P, Jirotkov D, Petráškov E, Raabová M, Smutný L, Jahnov Z and Smutná Š (2015). Influence of selected feed supplements on the growth and health of calves depending on the sex, season of birth, and number of the dam's lactations. acta veterinaria, 84: 269-275. 